\title{
Effect of Silicon and Sulphur Fertilization on Growth and Yield of Rice
}

\author{
V. N. Patel*, K. C. Patel, A. S. Bhanvadia and D. Kumar \\ Micronutrients Research Scheme, \\ Anand Agricultural University Anand-388110, Gujarat, India,
}

Silicon is considered an agronomically essential element for sustainable rice production (Savant et al. 1997a) and reported that adequate supply of Si increased the number of panicles, the number of grains per panicle, the percentage ripening and the lightreceiving posture of rice plants and also improved the availability and utilization of $\mathrm{P}$ by rice plants. $\mathrm{Si}$ is absorbed as PAS by rice plants in far larger quantities than the macro nutrients, $108 \%$ greater than nitrogen uptake. A rice crop producing a yield of $5000 \mathrm{~kg} \mathrm{ha}^{-1}$ removes $230-470 \mathrm{~kg} \mathrm{Si} \mathrm{ha}{ }^{-1}$ and it has the potential to raise the optimum rate of $\mathrm{N}$ (Elawad and Green 1979). It develops resistance and/or tolerance to abiotic stresses and could tolerate Fe, Al and Mn toxicities, and the increased mechanical strength of the culm helps reduce crop lodging (Takahashi 1995).

Sulphur is very much beneficial for increasing the production of rice via synthesis of chlorophyll, certain amino acids like methionine, cystine, cysteine and some plant hormones such as thiamine and biotin (Rahman et al. 2007) and growing of sulphur responsive crops, under high intensive cropping and use of sulphur free fertilizers caused S deficiency in soils of India (Tandon and Tiwari 2007).

In Gujarat, total area under rice cultivation was 7.82 lakh ha $^{-1}$ with total production of 19.3 lakh million tonnes and productivity of $2304 \mathrm{~kg} \mathrm{ha}^{-1}$ during 2016-17 and continuous cultivation of rice resulted in decreased rice production owing to deficiency of nutrients and lodging etc and hence present investigation was carried out to study the response of $\mathrm{Si}$ and $\mathrm{S}$ on kharif rice grown in a loamy sand soil at Anand.

*Corresponding author: (Email: vn9101@gmail.com)
The field experiments were conducted during the kharif season (2016-17 and 2017-18) at the Regional Research Station, Anand Agricultural University, Anand, Gujarat. The experimental loamy sand soil had pH 7.8, organic carbon $0.30 \%$, EC $0.23 \mathrm{dS} \mathrm{m}^{-1}$, available $\mathrm{Si}$ (68.73 $\left.\mathrm{mg} \mathrm{kg}^{-1}\right), \mathrm{P}_{2} \mathrm{O}_{5}\left(32.58 \mathrm{~kg} \mathrm{ha}^{-1}\right), \mathrm{S}$ (9.81 $\left.\mathrm{mg} \mathrm{kg}^{-1}\right)$, $\mathrm{Fe}\left(7.31 \mathrm{mg} \mathrm{kg}^{-1}\right)$ and $\mathrm{Zn}\left(1.23 \mathrm{mg} \mathrm{kg}^{-1}\right)$. There were 12 treatments comprising of four levels of $\mathrm{Si}(0,150,300$ and $450 \mathrm{~kg} \mathrm{ha}^{-1}$ applied through calcium silicate) and three levels of S $\left(0,20\right.$ and $40 \mathrm{~kg} \mathrm{ha}^{-1}$ applied through bentonite sulphur) as basal dose along with recommended NPK dose of fertilizers (120: 40: $00 \mathrm{~kg}$ $\left.\mathrm{ha}^{-1}\right)$. The experiment was laid out in Factorial Randomized Block Design with three replications. All the biometric observations were taken at the time of harvest. The experimental data were analyzed as per the procedure outlined by Steel and Torrie (1982).

The application of $450 \mathrm{~kg} \mathrm{Si} \mathrm{ha-1}$ gave significantly higher total number of tillers per meter row length $(87.95,90.18$ and 89.06$)$ of rice in both the years as well as on a pooled basis than control, but it was at par with $300 \mathrm{~kg} \mathrm{Si} \mathrm{ha}^{-1}$ (Table 1) might be due to the role of silicon in cell division, photosynthetic process as well as in the formation of chlorophyll. Liang et al. (1996) and Mauad et al. (2003) also reported similar findings.

Application $450 \mathrm{~kg} \mathrm{Si} \mathrm{ha}{ }^{-1}$ also resulted in significantly higher plant height than control but it was at par with 150 and $300 \mathrm{~kg} \mathrm{Si} \mathrm{ha}^{-1}$ during first year but in case of second year and pooled basis it was at par with (Si300) and differed significantly from (Si0) and (Si150) treatments (Table 1). Gascho and Korndorfer (1998) observed that both soil and plant parameters were significantly affected by the Si sources and rates 
used while Fallah (2012) reported improved plant height, inter-node length and fresh weight in rice .

Application of $40 \mathrm{~kg} \mathrm{~S} \mathrm{ha}^{-1}$ brought significantly higher total number of tillers per meter row length $(86.06,88.41$ and 87.24$)$ of rice in both the years as well as on a pooled basis than control (S0), but it was at par with $20 \mathrm{~kg} \mathrm{~S} \mathrm{ha}^{-1}$ (S20) in individual years, but differed significantly on pooled basis. The treatment ( $40 \mathrm{~kg} \mathrm{~S} \mathrm{ha}$ $\left.{ }^{1}\right)$ had significantly higher plant height than the control, but it was at par with $20 \mathrm{~kg} \mathrm{~S} \mathrm{ha}^{-1}$ during first and second year as well as on pooled basis (Table 1).

In pooled data, the highest total numbers of tillers per meter row length (95.21) were observed in treatments having $450 \mathrm{~kg} \mathrm{Si} \mathrm{ha}^{-1}$ and $40 \mathrm{~kg} \mathrm{~S}^{-1}{ }^{-1}$ which was found to be at par with $300 \mathrm{~kg} \mathrm{ha}^{-1} \mathrm{Si}$ and $40 \mathrm{~kg} \mathrm{ha}^{-1} \mathrm{~S}$ application, but differed significantly from the rest of the combinations (Table 1). These results are in conformity with the findings of Sudhakar et al. (2004). The significantly highest grain yield was recorded due to 450 $\mathrm{kg} \mathrm{ha}^{-1} \mathrm{Si}$ during both the years as well as on a pooled basis (Table 2). The significantly highest straw yield was recorded due to $450 \mathrm{~kg} \mathrm{ha}^{-1} \mathrm{Si}$ during both the years as well as on pooled basis, respectively (Table 2). The increased in yield with Si application could be due to beneficial effects viz., decreasing mutual shading by improving leaf erectness, decreasing susceptibility to lodging, decreasing the incidence of pathogens. The results are in line with the findings of Savant et al. (1997). Chen et al. (2011) stated that silicon application increased grain yield by increase of spikelet number, filled spikelet percentage and 1000-seed weight.

The significantly highest grain yield was recorded due to sulphur application @ $40 \mathrm{~kg} \mathrm{ha}^{-1}$ during both the years as well as on a pooled basis but it was at par with $20 \mathrm{~kg} \mathrm{Si} \mathrm{ha}^{-1}$ during both the years as well as on a pooled basis. The highest straw yield was recorded due to sulphur application@ $40 \mathrm{~kg} \mathrm{ha}^{-1}$ but it was at par with $20 \mathrm{~kg} \mathrm{Si} \mathrm{ha}^{-1}$ (Table 2). The increased rice yields might be due to enhanced leaf-chlorophyll favourably influenced by Sulphur availability in soil resulting in the formation of relatively bold grain leading to increased yield (Rahman et al. 2007).

Table 1. Effect of silicon and sulphur on total number of tillers per meter row length and plant height

\begin{tabular}{ccccccc}
\hline & \multicolumn{3}{c}{ Total number of tillers per meter row length } & \multicolumn{3}{c}{ Plant height (cm) } \\
\cline { 2 - 7 } Treatment & $\mathbf{2 0 1 6 - 1 7}$ & $\mathbf{2 0 1 7 - 1 8}$ & Pooled & $\mathbf{2 0 1 6 - 1 7}$ & $\mathbf{2 0 1 7 - 1 8}$ & Pooled \\
\hline Silicon levels (kg ha ${ }^{-1}$ ) & & & & & & \\
Si0 & 77.59 & 79.19 & 78.39 & 98.94 & 102.13 & 100.53 \\
Si150 & 81.69 & 82.65 & 82.17 & 104.40 & 106.91 & 105.65 \\
Si300 & 84.80 & 86.18 & 85.49 & 106.63 & 111.70 & 109.16 \\
Si450 & 87.95 & 90.18 & 89.06 & 109.17 & 115.97 & 112.57 \\
S.Em. \pm & 1.49 & 1.96 & 1.03 & 1.92 & 2.34 & 1.86 \\
CD (P=0.05) & 4.38 & 5.76 & 3.01 & 5.63 & 6.87 & 5.47 \\
Sulphur levels (kg ha ${ }^{-1}$ ) & & & & & & \\
S0 & 80.37 & 81.01 & 80.69 & 101.30 & 105.57 & 103.43 \\
S20 & 82.59 & 84.23 & 83.41 & 105.22 & 108.90 & 107.06 \\
S40 & 86.06 & 88.41 & 87.24 & 107.69 & 113.07 & 110.38 \\
S.Em. \pm & 1.29 & 1.70 & 0.89 & 1.66 & 2.03 & 1.61 \\
CD (P=0.05) & 3.80 & 4.99 & 2.61 & 4.88 & 5.95 & 4.74 \\
Significant interactions & Si S & Si S & Si S & - & - & - \\
CV \% & 5.40 & 6.96 & 6.90 & 5.50 & 6.43 & 4.65 \\
\hline
\end{tabular}


Table 2. Effect of silicon and sulphur on grain yield $\left(\mathrm{kg} \mathrm{ha}^{-1}\right)$ and straw yield $\left(\mathrm{kg} \mathrm{ha}^{-1}\right)$

\begin{tabular}{|c|c|c|c|c|c|c|}
\hline \multirow[b]{2}{*}{ Treatment } & \multicolumn{3}{|c|}{ Grain yield $\left(\mathrm{kg} \mathrm{ha}^{-1}\right)$} & \multicolumn{3}{|c|}{ Straw yield $\left(\mathrm{kg} \mathrm{ha}^{-1}\right)$} \\
\hline & 2016-17 & 2017-18 & Pooled & 2016-17 & 2017-18 & Pooled \\
\hline \multicolumn{7}{|c|}{ Silicon levels $\left(\mathrm{kg} \mathrm{ha}^{-1}\right)$} \\
\hline Si0 & 5680 & 5736 & 5708 & 7184 & 7348 & 7248 \\
\hline Si150 & 5791 & 5816 & 5804 & 7379 & 7553 & 7466 \\
\hline Si300 & 5902 & 5953 & 5928 & 7610 & 7705 & 7658 \\
\hline Si450 & 6211 & 6294 & 6252 & 8025 & 8159 & 8092 \\
\hline S.Em. \pm & 128 & 144 & 128 & 196 & 174 & 175 \\
\hline $\mathrm{CD}(\mathrm{P}=0.05)$ & 378 & 422 & 377 & 576 & 511 & 513 \\
\hline \multicolumn{7}{|c|}{ Sulphur levels $\left(\mathrm{kg} \mathrm{ha}^{-1}\right)$} \\
\hline So & 5667 & 5704 & 5686 & 7205 & 7356 & 7281 \\
\hline $\mathbf{S 2 0}$ & 5938 & 5954 & 5946 & 7576 & 7733 & 7655 \\
\hline S40 & 6084 & 6191 & 6137 & 7893 & 7984 & 7912 \\
\hline S.Em. \pm & 111 & 124 & 111 & 170 & 151 & 151 \\
\hline $\mathrm{CD}(\mathrm{P}=0.05)$ & 327 & 366 & 327 & 499 & 443 & 444 \\
\hline \multicolumn{7}{|l|}{ Significant } \\
\hline interactions & - & - & - & - & - & - \\
\hline CV \% & 6.56 & 7.27 & 3.43 & 7.82 & 6.81 & 3.60 \\
\hline
\end{tabular}

\section{Conclusion}

It is concluded that application of $300 \mathrm{~kg} \mathrm{Si} \mathrm{ha}^{-1}$ and $20 \mathrm{~kg}$ $\mathrm{S} \mathrm{ha}^{-1}$ with recommended dose of fertilizer (120-40-00 $\left.\mathrm{kg} \mathrm{ha}^{-1}\right)$ may result in optimum yield of grain and straw in rice.

\section{References}

Chen, J. X., Tu, N. M., Yi, Z. X. and Zhu, H. L. (2011). Effect of silicon fertilizer on nitrogen utilization efficiency of super early rice. Cereal Crop Research 1,6.

Elawad, S. H. and Green, V. E. (1979). Silicon and the rice plant environment: A Review of Recent Research. II Riso 28, 235-253.

Fallah, A. (2012). Study of silicon and nitrogen effects on some physiological characters of rice. International Journal of Agriculture and Crop Sciences 4, 238-241.

Gascho, G.J. and Korndorfer, G. H. (1998). Availability of silicon from several sources as determined by chemical and biological methods. Agron. Abstr. Annual Meeting Am. Soc. Agron. Baltimore, MD.pp. 308.

Liang, Y., Shen, Q., Shen, Z. and Ma, T. (1996). Effect of silicon on salinity tolerance of two barley cultivars. Journal of Plant Nutrition 19, 173 183.

Mauad, M., Carlos, A. C. C., Helio, G. F. and Juliano, C. C. (2003). Nitrogen and silicon fertilization of upland rice. Scientia Agricola 60, 761-765.

Rahman, M. N., Islam, M. B., Sayem, S. M., Rahman, M. A. and Masud, M. M. (2007). Effect of different rates of sulphur on the yield and yield attributes of rice in old Brahmaputra floodplain soil. Journal of Soil and Nature 1, 22-26.

Savant, N. K., Datnoff, L. E. and Snyder, G. H. (1997). Depletion of plant available silicon in soils: a possible cause of declining rice yields. Communication in Soil Science and Plant Analysis 28, 1245-1252. 
Savant, N. K., Snyder, G. H. and Datnoff, L. E. (1997a). Silicon management and sustainable rice production. Advances in Agronomy 58, 151199.

Steel, R. G. and Torrie, J. H. (1982). Principles and procedures of statistics. McGraw Hill Book Company, New Delhi-110001.
Sudhakar, P. C., Singh, J. P. and Singh, K. (2004). Effect of silicon sources and fertility levels on transplanted rise. International Rice research Notes 29, 61-63.

Takahashi, E. (1995). Uptake mode and physiological functions of silica. Science Rice Plant 2, 58-71.

Tandon, H. L. S. and Tiwari, K. N. (2007). Fertiliser use in Indian agriculture-An eventful half century. Better Crops 1, 3 -5.

Received: July, 2018 Accepted: November, 2018 